\title{
A Scale Development Study to Determine the Self Efficacy Beliefs of University Students for English
}

Gürbüz Ocak

Prof., Afyon Kocatepe University, Turkey, gocak@aku.edu.tr

Burcu Karafil

Yalova University, Turkey, burcu.karafil@yalova.edu.tr

The aim of this study was to develop a self-efficacy belief for English scale for university students. For this purpose, a trial form of 73 items in Likert-type was prepared ant it was applied to a total of 365 university students in the fall semester of the 2016-2017 academic year. Explanatory factor analysis was conducted to prove the construct validity of the developed scale. For the factor analysis of the data, it was shown that the data set was suitable for factor analysis as the KMO value was 0,97 and the Barlett test significance value was 0,000. The analyses showed that the scale items were grouped under 5 factors, namely writing, speaking, reading, ability to learn English and listening, a total of 60 items. The value of Cronbach alpha calculated for reliability study was found as 0.98 . In the confirmatory factor analysis study, it was found that the values of the "Self-Efficacy Belief for English Scale" were acceptable $\left(\chi^{2} / \mathrm{df}=5.23\right.$; RMSEA $=.10$; CFI $=.83$; SRMR $=.085$ ). When the values of the other goodness of fit of the scale were examined, the values were obtained as GFI $=.55$, AGFI $=.52$; NNFI $=.83$ Findings related to the studies of validity and reliability show that the scale has a valid and reliable form.

Keywords: belief, English, reliability, self-efficacy, university student, validity

\section{INTRODUCTION}

Self-efficacy is one of the most important factors used in explaining the affective domain of learning and it is considered to have significant value with improvements in student-centered learning (Tuncer \& Tanaş, 2011). Self-efficacy refers to a motivation process in which activities are planned, the required skills are reviewed and the gains across the challenges are taken into account. Learners with high self-efficacy belief are more successful and gain personal growth. Moreover, they do not give up when they face a challenge and experience failure (Y1ldiz, 2014).

Self-efficacy is an important concept in terms of education. Bandura (1996) stated that learners' beliefs in their capabilities affect performance tremendously. Self-efficacy provides a basis for personal motivation, success and welfare. When the learners believe themselves in the activities they make, they try more (Pajares, 2002). Learners with high self-efficacy cope with difficulties they encounter, have higher motivation for learning, are more willing to learning, and therefore become more successful (Arslan, 2012). Moreover, self-efficacy is a key factor that affects learners' interest, persistence, student effort in learning, the goals they set and use of self-regulated strategies in performing a task (Lane, Lane, \& Kyprianou, 2004).

Self-efficacy also affects foreign language learners' performance. Foreign language learning process is greatly influenced by previous experiences as language learners (Horwitz, 1987). It is suggested that

Citation: Ocak, G., \& Karafil, B. (2020). A Scale Development Study to Determine the Self Efficacy Beliefs of University Students for English. Anatolian Journal of Education, 5(1), 53-66. https://doi.org/10.29333/aje.2020.516a 
learners' beliefs about language learning would likely affect how they use their learning strategies and learn a foreign language (Mills, Pajares \& Herron 2006; Rahimi \& Abedini, 2009). Therefore, selfefficacy should be examined in foreign language learning process.

\section{Literature Review}

As a result of developments in science, art and technical field, language has become the most important tool used by people to communicate with each other. Moreover, as a consequence of globalization, people need to be able to communicate behind the borders, not just within the borders of their own country. Therefore, communication becomes the most important tool in the interaction of people. In our global world, English language is used in international relations and communication (Anyadabulu, 2006). Therefore, the number of individuals who want to learn English language is increasing day by day.

There are many factors affecting the learning of a new language process. It is seen that in a foreign language learning process some students have higher levels of motivation and participation than others. In addition, although some learners take part in the same learning environment, they have lower level of interest (Ersanl1, 2015). Therefore, it can be said that individual differences are important in the success of foreign language learning (Raoofi, Tan \& Chan, 2012). Moreover, individual differences are the key factors in academic achievement and motivation (Ehrman, Leaver \& Oxford, 2003). As a result, it is important to investigate individual differences affecting foreign language success (Doordinejad \& Afshar, 2014). One of the affective factors affecting student achievement is the students' beliefs on their own potentials, namely self-efficacy beliefs (T1lfarlığlu \& Cinkaya, 2009; Üncü, 2012). Self-efficacy belief is said to have a great influence on student achievement significantly in foreign language learning process (Ehrman et al., 2003, Rahemi, 2007, Rahmi \& Abedini, 2009).

Self-efficacy is an important concept that stands out in Bandura's Social Cognitive Theory. Selfefficacy is the belief in an individual's ability to show a given performance at the desired level (Bandura, 1996). According to Senemoğlu (2000), self-efficacy is the self-judgment of the individuals about their ability to cope with different situations and to succeed in a particular activity. Self-efficacy in this context is the belief in what individuals can do using their skills in a particular situation (Maddux, 2002). Therefore, self-efficacy belief is the most important determinant of individual behaviors.

Bandura (1996) notes that self-efficacy belief affects the basic and important elements such as academic motivation, efforts of individuals, resistance and emotional reactions. Sharp (2002) states that self-efficacy belief is a fundamental criterion that determines the individual's personal success, motivation and personal accomplishment. Self-efficacy beliefs directly influence the efforts and resistance of individuals towards difficulties (Pajares (2002) and influence individuals' achievements (Gahunga, 2010). In addition, self-efficacy beliefs have important influence on students' academic achievement. In other words, self-efficacy belief affects the performance and academic success of students (Zimmerman, 2000). Moreover, in the studies explaining the psychological dimension of the learners, it is generally stated that self-efficacy positively influences learning.

Bandura (1996) states that students with low self-efficacy beliefs are less likely to learn, while those with high self-efficacy beliefs have high learning efforts. Moreover, students with higher self-efficacy belief level have a positive attitude towards learning and control their own learning processes (Deci and Ryan, 1985; Weimer, 1986). In this context, students with high self-efficacy beliefs try to overcome the difficult tasks. Self-efficacy belief increases the learning motivation of students. Students with low level of self-efficacy beliefs are less willing to learn and do not make any effort when they face difficulties. Self-efficacy beliefs in foreign language teaching are not related to the 
quantity of what is known about this language. It is about the quality of activities that can be done with the language, such as reading, writing, speaking and listening. The perception of how competent the person is about these skills is related to self-efficacy belief (Büyükduman, 2006). According to Chenfeld (1978), there are four basic skills in foreign language teaching. These skills are listening, speaking, reading and writing. It is impossible for these skills to be separated. By participating in the language learning process, students can gain these skills. People can share their experiences by talking. In addition, newspapers and magazines cannot be used without reading. Writing skills are necessary to prepare a social project in a similar way. It is also impossible to follow an arithmetic problem without listening skills. Therefore, all skills are involved in language learning process (Yanar, 2008). Within this context, it can be concluded that self-efficacy belief in a foreign language consists of all the skills.

In literature, there have been some studies on foreign language self-efficacy beliefs of students. Cheng (2001) examined the relationship between foreign language learning self-efficacy, competence belief, and foreign language anxiety. Hsieh (2004) examined the relationship between qualifications of foreign language learners, self-efficacy, general language learning beliefs and achievements in foreign language courses. Büyükduman (2006) examined whether there is a relationship between English teacher candidates' perceptions of English self-efficacy and teacher self-efficacy perceptions. Chen (2007) investigated the relationship between self-efficacy perceptions and English performance of English learners. Yanar (2008) examined the relationship between high school students' foreign language self-efficacy beliefs and attitudes towards English. Ho (2016) examined the relationship between university students' writing anxiety and self-efficacy beliefs in foreign language classes.

Scales are generally used to determine the self-efficacy beliefs of students. When the literature is reviewed, it is seen that there are some scales used to measure the English self-efficacy of students. The self-efficacy beliefs of students for English speaking (Yang, 1999; Asakereh \& Dehghannezhad, 2015), English writing (Erhan \& Saban, 2011), English listening (Chen, 2007; Rahimi \& Abedini, 2009; Todaka, 2016; Ho, 2016) and English reading (Li \& Wang, 2010) are measured by scales. Moreover, in some scales (Zheng, Young, Brewer \& Wagner, 2009; Tilfarlioglu \& Cinkara, 2009; Yanar \& Bümen 2012) the four skills are investigated. However, it is seen that most of the studies are conducted on high school students and the scales are seen not to cover all the aspects of the skills. Therefore, this study aimed to develop a valid and reliable scale to measure self-efficacy beliefs of university students for English. The scale developed in this context is intended to measure the university students' self-efficacy beliefs related to English and thus to contribute to the effectiveness of the teaching and learning environments in improving the self-efficacy beliefs of the students and in increasing their effectiveness and efficiency in foreign language teaching.

\section{METHOD}

\section{Participants of the Study}

The participants of the study consisted of 365 students studying at Bilecik Seyh Edebali University, Turkey in the fall semester of 2016-2017 academic year. To determine the participants, among the purposeful sampling methods, convenience sampling method was used. This method gives speed and practicality to the research (Yıldırım \& Şimşek, 2006). The participants consisted of 183 male and 182 female students. Moreover, the students were studying at five different faculties as Health Vocational High School (60 students), Foreign Language department (65), Engineering Faculty (32), Central Vocational High School (110) and Osmaneli Vocational High School (65). In addition, 95 of the students were studying at first grade, 205 of the students were studying at second grade and 60 of them were studying at preparation class. 


\section{Procedure}

In the scale development process, firstly the literature was reviewed and the related studies (Yang, 1999; Chen, 2007; Tilfarlıoğlu \& Cinkaya, 2009; Rahimi \& Abedini, 2009; Li \& Wang, 2010; Erkan \& Saban, 2011; Wang et al., 2012; Yanar \& Bümen, 2012; Zheng et al.,2012; Wang et al.,2013; Rahemi, 2013; Asakereh \& Dehghannezhad, 2015; Ho, 2016) were examined in order to develop a reliable scale. In this way, a general framework for self-efficacy belief for English language was established. Moreover, two open-ended questions were asked to two English lecturers working at Bilecik Seyh Edebali University, Turkey and an expert studying at Afyon Kocatepe University, Turkey. Meanwhile three open-ended questions about self-efficacy concept were asked to students studying at Bilecik Seyh Edebali University Optimal Preparation Class. With the obtained data, it was aimed to generate an item pool and develop statements related to English self-efficacy belief. The generated statements were intended to cover self-efficacy beliefs of university students for English. In initial stage, 73 statements consisting of five dimensions as reading, writing, listening, speaking and ability to learn English were developed to measure the self-efficacy beliefs of the students for English. 62 of the statements were about cognitive field while 11 were related to affective field. All the statement roots were positive. The extensive review of literature guided the researchers to use Likert formant in the scale. Likert scaling is a commonly used tool measuring beliefs, options and attitudes (DeVellis, 2016). Therefore the present scale comprised 5-point Likert format, each statement is rated on five sequential points as "never suits me $=1$, slightly suits $m e=2$, somewhat suits $m e=3$, quite suits $m e=4$ and completely suits $m e=5$ ".

After preparing the item pool, the face and content validity was qualitatively performed with the involvement of four experts in the field of curriculum and instruction and who have experience in education. The experts expressed their opinions about any ambiguity, vagueness or dual meaning related to statements. Based on the advice from experts, necessary revisions were performed.

\section{Data analysis}

In order to test the reliability and validity of self-efficacy belief for English scale, it was applied to 365 university students, who were the participants of the study. The Kaiser-Meyer Olkin (KMO) coefficient was applied to determine whether the sampling size was appropriate for factorization or not. The KMO coefficient varies from 0 to 1 and the acceptable minimum limit of the KMO sampling capability is 0.50 . Barlett Test of Sphericity was applied to determine whether there is sufficient correlation between variables. For this test, the significance value smaller than .05 shows that there is a sufficient level of correlation between variables (Durmuş, Yurtkoru \& Çinko, 2011).

The validity assessment of the scale was performed by examining the structural validity. For the structural validity, the factorial structure of the scale was determined by using the Explanatory Factor Analysis (EFA) and Confirmatory Factor Analyses (CFA). EFA is an analysis used to determine the items that measure the same structure. Factor loads are the first criterion to be taken as a basis for factor analysis. Items with a factor load below .30 need to be removed from the analysis. Generally, items with a factor load of .40 or higher are selected (Büyüköztürk, 2010). Another criterion to be taken as a basis for factor analysis is that an item should have value under one factor. Therefore, it is necessary to remove the items having value under more than one factor (Büyüköztürk, 2010).

On the other hand, CFA was applied. CFA allows the researchers to impose a structure or model on the data. It is used to determine how items are associated with each other, to test how well the model fits, whether the factors are correlated or uncorrelated. Many fit indices are used in order to determine the adequacy of the model tested in CFA (Joreskog \& Sorbom, 1993). In this study, the Chi-Square 
Goodness Test, Goodness of Fit Index (GFI), Adjusted Goodness of Fit Index (AGFI), Comparative Fit Index (CFI), and Root Mean Square Error of Approximation (RMSEA) were examined for CFA.

\section{FINDINGS}

In this section, the findings on reliability and validity tests conducted to develop English self-efficacy belief scale are presented.

\section{Exploratory Factor analysis}

For the exploratory factor analysis, firstly Kaiser-Meyer-Olkin (KMO) and Bartlett's Sphericity tests were applied to determine the suitability of the obtained data. The results are given in Table 1 below:

Table 1

KMO and Bartlett's Test of Sphericity

\begin{tabular}{lll}
\hline Kaiser-Meyer-Olkin Measure of Sampling Adequacy. & .979 \\
& Approx. Chi-Square & 26726.321 \\
Bartlett's Test of Sphericity & Df & 1770 \\
& Sig. & .000 \\
\hline
\end{tabular}

As seen in Table 1, KMO value for factor analysis of 73 items was calculated as .97. KMO value close to 1 indicates the suitability of the data for factor analysis. Moreover, it is seen that the results of the "Chi-square" test statistic obtained from the Bartlett's test were significant, $\chi 2=26726.321$, $\mathrm{df}=1770$, $\mathrm{p}<0.05$. As a result, the obtained values fit the basic hypotheses at a good level and it was decided that the factor analysis could be conducted.

After this step, exploratory factor analysis was conducted. As a result of the analysis, the 73 items of the scale were reduced to 60 items. The factor analysis revealed a five factor structure. The items with the Eigen value greater than 1.00 were included in the scale. According to the explanatory total variance analysis, the first factor explains the $17.871 \%$ of the total variance, the second factor explains the $17.853 \%$ of the total variance, the third factor explains the $15.348 \%$ of the total variance, the fourth factor explains the $13.918 \%$ of the total variance and the fifth factor explains the $8.317 \%$ of the total variance. Moreover, the five factor structure explains the $73.357 \%$ of the total variance.

After these processes, the last form of the English language self-efficacy belief scale was given as 60 items. The rotated components matrix, which was converted with Varimax method, and which was obtained as a result of the exploratory factor analysis, is given in table 2 . The Varimax method is one of the vertical rotating methods and it was preferred in the analysis to ensure that the factor variances would have high value with a few variables. 
Table 2

Factor Loadings of Self Efficacy Beliefs for English Scale

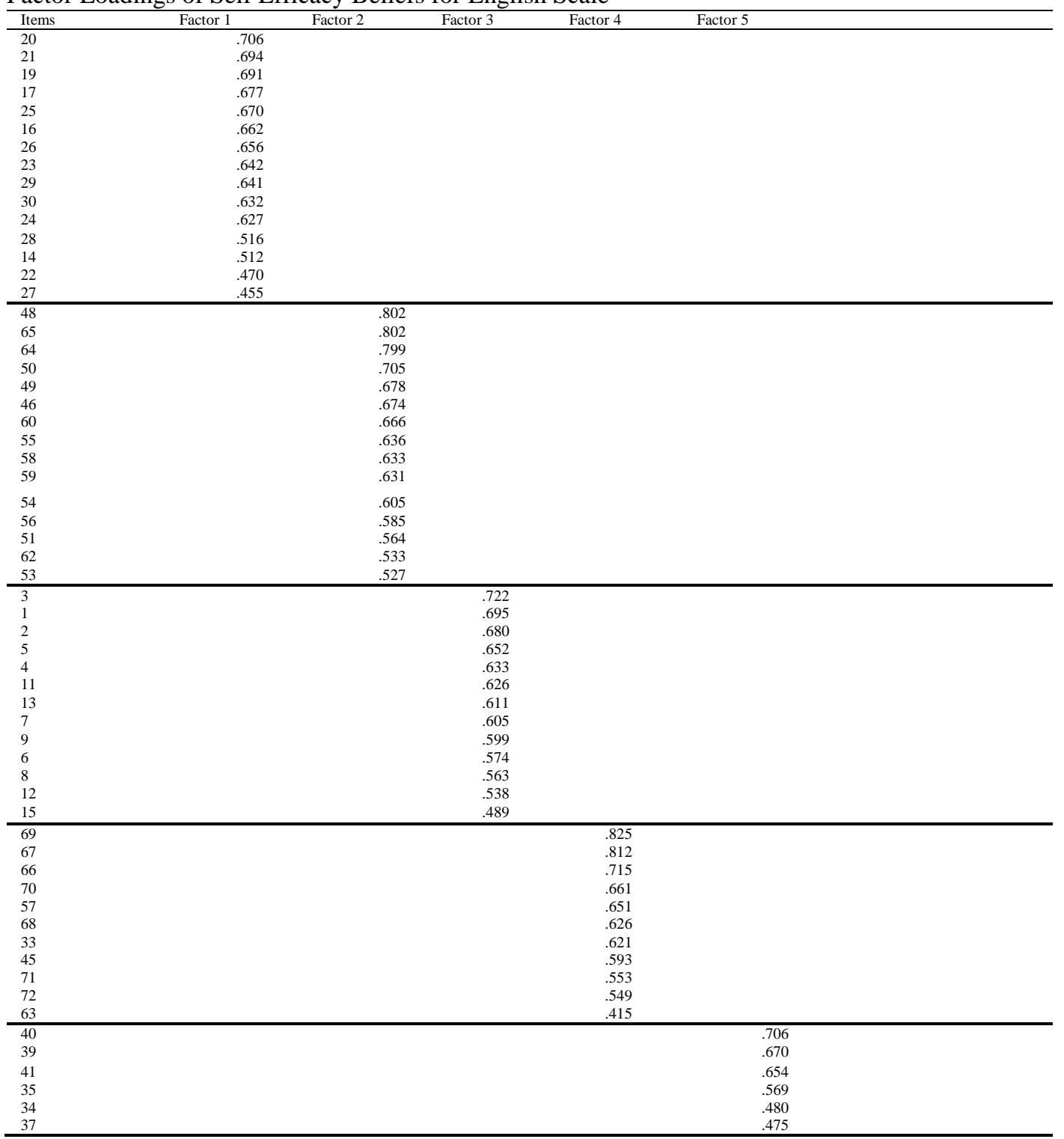

As seen in Table 2, first factor consists of 15 items associated to writing in English, second factor consists of 15 items associated to speaking in English, third factor consists of 13 items, associated to reading in English, fourth factor consists of 11 items associated to ability to learn English and fifth factor consists of 6 items associated to listening in English.

\section{Confirmatory Factor Analysis}

In order to test the structure validity of the scale and accuracy of sub-dimensions obtained by the Exploratory Factor Analysis, Confirmatory Factor Analysis (CFA) was

Anatolian Journal of Education, April $2020 \bullet$ Vol.5, No.1 
applied using LISREL program. CFA is a version of factor analysis which tests the specific hypotheses about structure and relations between the latent variables that underlie the data (Field, 2009).

The obtained fit indexes were evaluated according to the fit indexes stated in literature. Firstly, fit indices were examined to evaluate the overall fit. Chi Square $(\chi 2)$, RMSEA, NFI, NNFI, CFI, GFI, and AGFI are the most commonly used statistical analysis in model data fit structure. The error and fit index in items are presented in Table 3.

Table 3

Error and Fit Index for Self Efficacy Belief for English Scale

\begin{tabular}{llll}
\hline Fit Index & The Values of the Scale & Good Fit Index Values & Acceptable Fit \\
\hline$\chi 2 / \mathrm{df}$ & 5.23 & $0 \leq \chi 2 / \mathrm{df} \leq 5$ & $2<\chi 2 / \mathrm{df} \leq 5$ \\
\hline RMSEA & .10 & $0 \leq \mathrm{RMSEA} \leq .05$ & $.05<\mathrm{RMSEA} \leq .08$ \\
\hline Comperative Fit Index (CFI) & .83 & $.95 . \leq \mathrm{CFI} \leq .97$ & $.0 \leq \mathrm{CFI}<.1 .00$ \\
\hline Standartized RMR & .085 & $.05 \leq \mathrm{SRMR} \leq .08$ & $.0<\mathrm{SRMR} \leq 1.00$ \\
\hline Goodness of Fit Index (GFI) & .55 & $.90 \leq \mathrm{GFI} \leq 1.00$ & $.0 \leq \mathrm{GFI}<1.00$ \\
\hline Adjusted Goodness of Fit Index (AGFI) & .52 & $.90 \leq \mathrm{AGFI} \leq 1.00$ & $.0 \leq \mathrm{AGFI}<1.00$ \\
\hline NNFI & .83 & $.80 \leq \mathrm{NNFI} \leq .95$ & $.0 \leq \mathrm{NNFI}<1.00$ \\
\hline
\end{tabular}

Source: Hooper, Coughlan and Mullen, 2008; Kline, 2011; Tabachnick and Fidell, 2013.

As seen in Table, chi-square goodness-of-fit $\left(\chi^{2}\right)$ is statistically significant. However, Çokluk, Şekercioğlu and Büyüköztürk (2016) state that $\mathrm{x}^{2}$ rarely used as a sole index of the model fit. On the other hand, $(\chi 2 / \mathrm{df})$ is regarded as an adjunct discrepancy fit index. Therefore, $\chi 2 / \mathrm{df}$ is used to make an evaluation. As seen clearly in the Figure, $x^{2}=8904,53$ and $\mathrm{df}=1700 . x^{2} / \mathrm{df}$ is 5.23. In literature, it has been stated that if the ratio is between 2 to 5, it indicates an acceptable fit (Tabachnick and Fidell, 2007). Moreover Wheaton, Muthen, Alwin and Summers (1977) indicated that this ratio can be as high as 5. As seen, there is no clear consensus regarding the acceptable ratio for this statistic. On the other hand Jöreskog and Sörbom (1993) and Prudon (2015) state that when the large samples are used, $\chi 2$ locates many problems and therefore $\chi 2 / \mathrm{df}$ may suggest a poor fit. In this study, the sample size was large enough. In addition, MacCallum (2003) emphasizes that models can never be perfect and they unavoidably contain minor error. Based on these information, in this study $\chi 2 / \mathrm{df}$ ratio is accepted.

In the study, RMSEA was found as .10. When this value is closer to 0 , it shows a better fit of the model. Moreover, RMSEA in the range of 0.05 to 0.10 was considered an indication of fair fit (MacCallum, Browne and Sugawara, 1996). On the other hand, results indicated that GFI =.55, AGFI $=.52$, NNFI $=.83$ and $\mathrm{CFI}=.83$. All these indices are scaled from 0 (no fit) to 1 (perfect fit). Moreover, the values close to .95 are regarded as a good fit (Kline, 2011). Therefore, the results of CFA model of the Self Efficacy Belief for English Scale consisting of five factors provided a good model fit. Figure 1 below presents the factor distribution and the interaction among the subscales. 


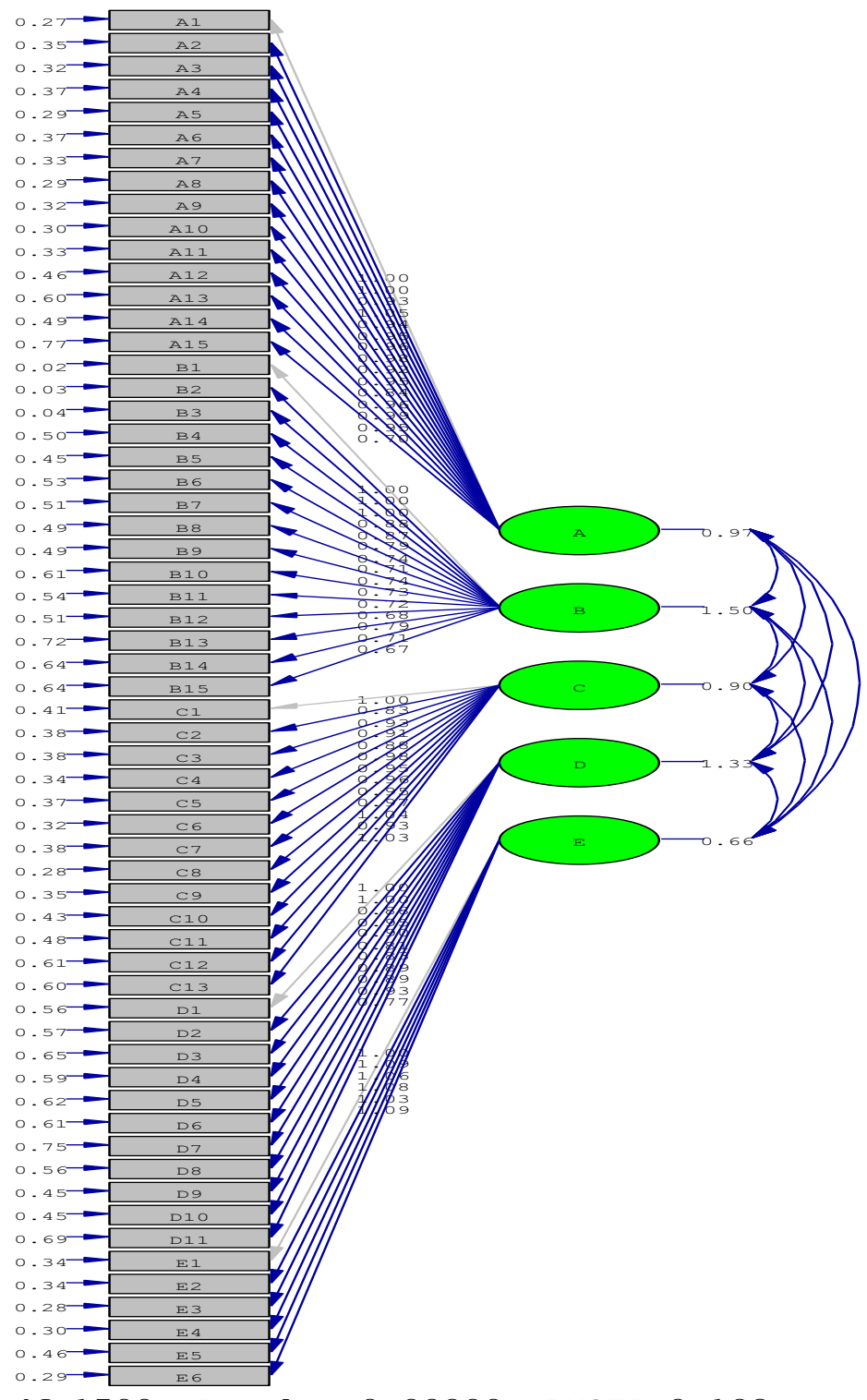

Figure 1

First Order Confirmatory Factor Analysis

In addition, the second order CFA of the Self Efficacy Belief for English Scale was conducted and the results are given in Figure 2. 


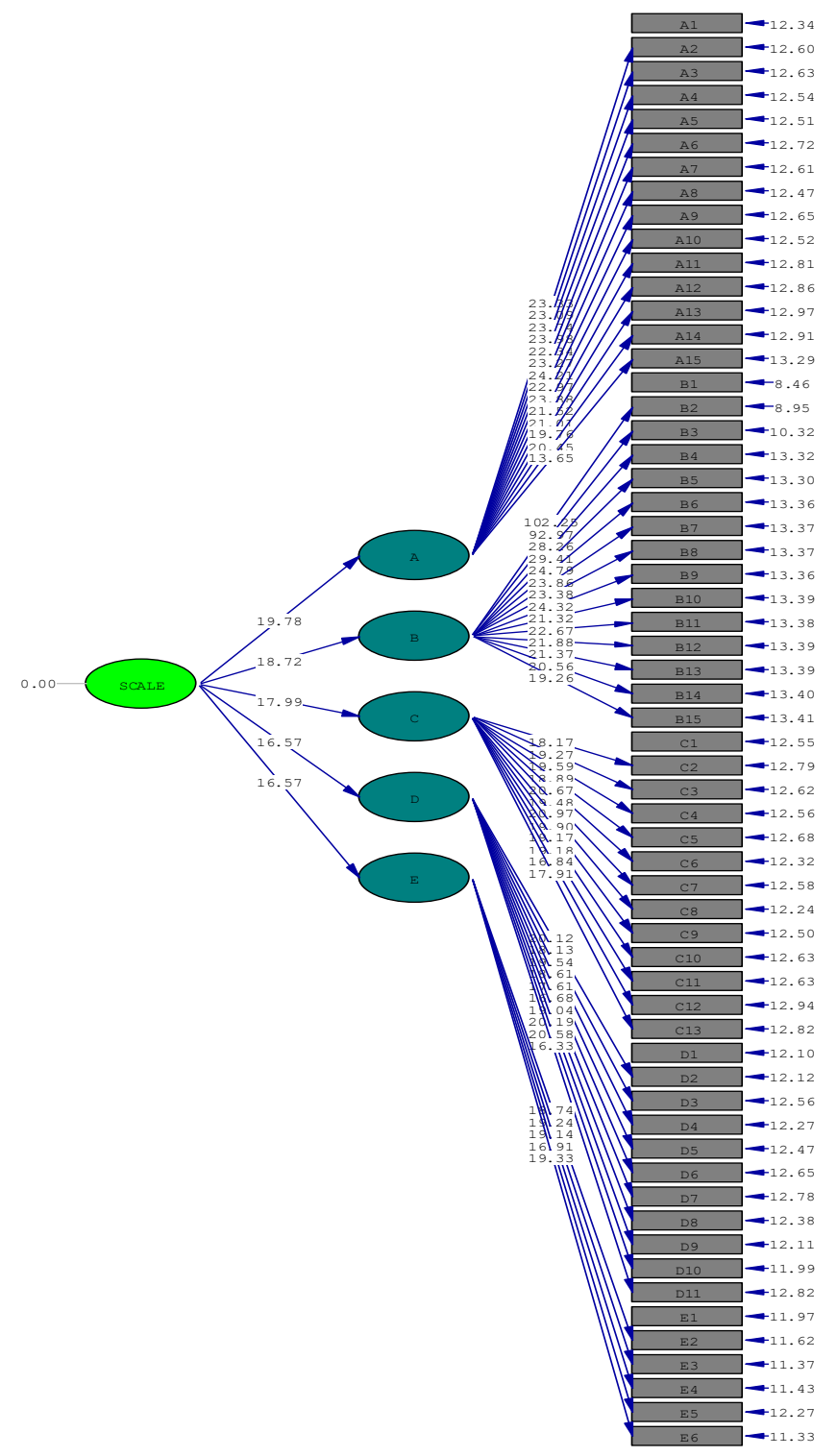

Figure 2

Second Order CFA Results

As seen in Figure 2, the $t$ values of the second order CFA related to the Self Efficacy Belief for English Scale are shown on the arrows. The parameter estimations were found significant at 01 . According to Çokluk, Şekercioğlu and Büyüköztürk (2016) t value higher than 2.56 is significant at .01 . The results showed that the values were within acceptable fit indexes.

\section{Reliability Analysis}

The reliability of the scale was measured by interpreting the obtained value of Cronbach's Alpha to assess the internal consistency of the scale. The results are given in Table 4. 
Table 4

Reliability Statistics of Self Efficacy Belief Scale for English

\begin{tabular}{ll}
\hline Factors & Cronbach Alpha \\
\hline Writing & .97 \\
Speaking & .97 \\
Reading & .96 \\
Ability to Learn English & .95 \\
Listening & .92 \\
\hline Total & .98 \\
\hline
\end{tabular}

As seen, Cronbach's Alpha value for the factors of the scale varies between .92 and .96 . Moreover, Cronbach's Alpha value for overall scale was found to be .98. An Alpha value higher than .70 is an expected condition for internal consistency (Rawwas \& Isakson, 2000). Therefore, for the scale Cronbach's alpha indicated good internal reliability $(\alpha=.98)$.

In addition, item total correlation analysis was conducted for the reliability of the scale. In scale development studies, item total correlation values should be greater than .25 In writing factor, item total correlation values are found to vary between .60 and .86. Moreover, the Cronbach Alpha values when item deleted vary between .96 and .97 . Item total correlation values for speaking factor vary between .81 and .90. Moreover, the Cronbach Alpha value when item deleted is .97. Item total correlation values for reading factor vary between .75 and .84. The Cronbach Alpha value when item deleted vary between .95 and .96 . Item total correlation values for ability to learn English factor vary between .68 and .83 . The Cronbach Alpha value when item deleted vary between .94 and .95 . Lastly, item total correlation values for listening factor vary between .73 and .82. The Cronbach Alpha value when item deleted vary between .91 and .92 .

\section{Intercorrelations of the Self Efficacy Belief for English Scale}

Pearson's coefficient of correlation was conducted to find the correlations between the factors of the scale. The obtained results are given in Table 5. As seen in table, Pearson's coefficient of correlation demonstrated higher levels of significant positive correlations of all dimensions of self-efficacy belief for English scale. The relationship between the ratio of 0.70-1.00 shows a high relationship (Büyüköztürk, 2010). Table 5 indicates that the model with best fit demonstrated inter-correlation between factors and self-efficacy belief for English scale

Table 5

Inter correlations for the Scale Factors

\begin{tabular}{lllllll}
\hline Measure & $\mathrm{W}$ & $\mathrm{S}$ & $\mathrm{R}$ & $\mathrm{ALE}$ & $\mathrm{L}$ & TESE \\
\hline $\mathrm{W}$ & 1 & $.86^{* *}$ & $.87^{* *}$ & $.76^{* * *}$ & $.82^{* *}$ & $.94^{* * *}$ \\
$\mathrm{~S}$ & $.86^{* *}$ & 1 & $.80^{* *}$ & $.81^{* * *}$ & $.78^{* *}$ & $.94^{* * *}$ \\
$\mathrm{R}$ & $.87^{* *}$ & $.80^{* *}$ & 1 & $.80^{* *}$ & $.79^{* *}$ & $.93^{* *}$ \\
$\mathrm{ALE}$ & $.76^{* *}$ & $.81^{* *}$ & $.80^{* *}$ & 1 & $.74^{* *}$ & $.86^{* *}$ \\
$\mathrm{~L}$ & $.82^{* *}$ & $.78^{* *}$ & $.79^{* *}$ & $.93^{* *}$ & 1 & $.87^{* *}$ \\
TESE & $.94^{* *}$ & $.94^{* *}$ & $.93^{* *}$ & $.89^{* *}$ & $.87^{* *}$ & 1 \\
\hline
\end{tabular}

Note: $\mathrm{W}=$ Writing; $\mathrm{S}=$ Speaking; $\mathrm{R}=$ Reading; ALE=Ability to Learn English; L=Listening; TESE= Total Self Efficacy Belief for English

\section{CONCLUSION}

The aim of this study was to develop a Self-Efficacy Belief Scale for English for university students. For this purpose, after a broad review of the relevant literature, an item pool was prepared. By doing so a general framework for self-efficacy belief in English skill was established. Moreover, two openended questions were asked to two English lecturers working at Bilecik Seyh Edebali University, Turkey and an expert studying at Afyon Kocatepe University, Turkey. Meanwhile three open-ended 
questions about self-efficacy concept were asked to students studying at Bilecik Seyh Edebali University Optimal Preparation Class. Therefore, an initial form consisting of 73 items were prepared. After preparing the item pool, the face and content validity was qualitatively performed with the involvement of four experts in the field of curriculum and instruction.

In order to test the reliability and validity of English self-efficacy belief scale, it was applied to 365 university students. The Kaiser-Meyer Olkin (KMO) coefficient was applied to determine whether the sampling size was appropriate for factorization or not. This value was calculated as .97 in the study. The validity assessment of the scale was performed by examining the structural validity. For the structural validity, the factorial structure of the scale was determined by using the Explanatory Factor Analysis (EFA) and Confirmatory Factor Analyses (CFA). As a result of EFA, 13 items were removed from the scale and the items were seen to group under five factors namely writing, speaking, reading, ability to learn English and listening. Moreover, in this study, the Chi-Square Goodness Test, Goodness of Fit Index (GFI), Adjusted Goodness of Fit Index (AGFI), Comparative Fit Index (CFI), and Root Mean Square Error of Approximation (RMSEA) were examined for CFA. The obtained values indicated good fit of the model.

The reliability of the scale was measured by Cronbach's Alpha. Cronbach's Alpha values for the factors of the scale were found to vary between .92 and .96. Moreover Pearson's coefficient of correlation was conducted to find the correlations between the factors of the scale. Pearson's coefficient of correlation demonstrated higher levels of significant positive correlations of all dimensions of English self-efficacy belief scale.

As a result of this study, a valid and reliable scale was obtained which can be used to reveal the selfefficacy beliefs of university students for English. Therefore, the scale can be studied on and with students who study English as a foreign language. Moreover, the factors in this study can be used separately do reveal the self-efficacy of the students related to sub skills of English.

\section{REFERENCES}

Ehrman, M. E., Leaver, B. L., \& Oxford, R. L. (2003). A brief overview of individual differences in second language learning. System, 31(3), 313-330.

Aktaş, T. \& İşigüzel, B. (2014). Yabancı dil öğretmenlerinin erken yaşta yabancı dil öğretimine ilişkin öz yeterlik algı düzeylerinin değerlendirilmesi. International Journal of Languages' Education and Teaching, 3, 17-24.

Anyadubalu, C. (2010). Self-efficacy, anxiety, and performance in the English language among middle-school students in English language program in Satri Si Suriyothai, Bangkok. International Journal of Social Science, 5(3), 193-198.

Arslan, İ. (2012). İlköğretim öğrencilerinin öz yeterlik inancı kaynaklarının öğrenme ve performansla ilgili öz yeterlik inancını yordama gücü. Kuram ve Uygulamada Ĕgitim Bilimleri, 12(3), 1907-1920.

Asakereh, A., \& Dehghannezhad, M. (2015). Student satisfaction with EFL speaking classes: Relating speaking self-efficacy and skills achievement. Issues in Educational Research, 25(4), 345-363.

Bandura, A. (1996). Self-efficacy in changing societies. New York: Cambridge University Press

Büyükduman, F. (2006). Ingilizce öğretmen adaylarının İnilizce ve öğretmenlik becerilerine ilişkin öz-yeterlik inançları arasındaki ilişki. (Unpublished doctoral dissertation). Yıldız Teknik Üniversitesi, İstanbul.

Büyüköztürk, Ş. (2010). Sosyal bilimler için veri analizi el kitabı. Ankara: Pegem Akademi Yayıncilık. 
Chenfeld, M. B. (1978). Teaching language arts creatively. Charlotte: Harcourt Brace Javonavich, Inc

Chen, H. (2007). The relationship between EFL learners' self-efficacy beliefs and english performance (Unpublished doctoral dissertation). Florida State University, United States.

Cheng, Y. S. (2001). Learners' beliefs and second language anxiety. Concentric: Studies in English Literature and Linguistic. 27, (2), 75-90.

Çimen, S. (2011). Eğitim fakültesi öğrencilerinin İngilizceye yönelik tutum, İngilizce kaygısı ve öz yeterlik düzeylerinin incelenmesi. (Unpublished master thesis). Zonguldak Karaelmas Üniversitesi, Zonguldak.

Çoban, T. A., \& Sanalan, V. A. (2002). Fen bilgisi öğretimi dersinde özgün deney tasarım sürecinin öğretmen adaylarının özyeterlik algısına etkisi. Erzincan Eğitim Fakültesi Dergisi, 4(2), 1-10.

Deci, E., \& Ryan, R. M. (1985). Intrinsic motivation and self-determination in human behavior. Springer Science \& Business Media.

DeVellis, R. F. (2016). Scale development: Theory and applications (Vol. 26). Sage publications.

Doordinejad, F. G., \& Afshar, H. (2014). On the relationship between self-efficacy and English achievement among Iranian third grade high school students. International Journal of Language Learning and Applied Linguistics World, 6(4), 461-470.

Durmuş, B., Yurtkoru, E. S., Çinko, M. (2011). Sosyal bilimlerde SPSS'le veri analizi. İstanbul: Beta Yayıncilik

Ehrman, M. E., Leaver, B. L., \& Oxford, R. L. (2003). A brief overview of individual differences in second language learning. System, 31(3), 313-330.

Ekici, G. (2012). Akademik öz-yeterlik ölçeği: Türkçe'ye uyarlama, geçerlik ve güvenirlik çalışması. Hacettepe Üniversitesi Ë̆itim Fakültesi Dergisi, 43, 174-185.

Erkan, Y. D., \& Saban, A. I. (2011). Writing performance relative to writing apprehension, selfefficacy in writing, and attitudes towards writing: A correlational study in Turkish tertiary-level EFL. The Asian EFL Journal Quarterly, 13(1), 163-191.

Ersanl, C. Y. (2015). The relationship between students' academic self-efficacy and language learning motivation: A study of 8th graders. Procedia-Social and Behavioral Sciences, 199, 472-478.

Field, A. (2009). Discovering statistics using SPSS. Sage publications

Gahunga, O. (2010). Are self-efficacy, language learning strategies, and foreign language ability interrelated? The Buckingham Journal of Language and Linguistics, 2, 47-60.

Gömleksiz, M. N. (2003). İngilizce duyuşsal alana ilişkin bir tutum ölçeğinin geçerlik ve güvenirliği. Firat Üniversitesi Sosyal Bilimler Dergisi,13(1), 215-226

Gürcan, A. (2005). Bilgisayar öz yeterliği algısı ile bilişsel öğrenme stratejileri arasındaki ilişki. Eğitim Araştırmaları, 19, 179-193.

Hsieh, P. H. (2004). How college students explain their grades in a foreign language course: The interrelationship of attributions, self-efficacy, language learning beliefs, and achievement. (Unpublished doctoral dissertation). University of Texas.

Ho, M. C. (2016). Exploring writing anxiety and self-efficacy among EFL graduate students in Taiwan. Higher Education Studies, 6(1), 24-39. 
Horwitz, E. K. (1989). Recent research on second language learners: Beliefs and anxiety. Negotiating for meaning: Papers on foreign language teaching and evaluation. Austin, TX: University of Texas at Austin, Department of Foreign Language Education Studies.

Hooper, D., Coughlan, J., \& Mullen, M. (2008). Structural equation modelling: Guidelines for determining model fit. Electronic Journal of Business Research Methods, 6, 53-60.

Jöreskog, K. G., \& Sörbom, D. (1993). LISREL 8: Structural equation modeling with the SIMPLIS command language. Scientific Software International.

Karakış, Ö. (2014). Lise öğrencilerinin Ingilizce dersine yönelik kaygıları, motivasyonlarl, öz-yeterlik algıları ve İngilizce ders başarıları arasındaki ilişki. (Unpublished master thesis). Abant İzzet Baysal Üniversitesi, Bolu.

Kiremit, H.Ö. (2006). Fen bilgisi öğretmenliği öğrencilerinin biyoloji ile ilgili öz yeterlik inançlarının karşılaştırılması. (Unpublished doctoral dissertation). Dokuz Eylül Üniversitesi, İzmir.

Lane, J., Lane, A., \& Kyprianou, A. (2004). Self-efficacy, self-esteem and their impact on academic performance. Social Behaviour and Personality, 32, 247-256.

Li, Y., \& Wang, C. (2010). An empirical study of reading self-efficacy and the use of reading strategies in the Chinese EFL context. Asian EFL Journal, 12(2), 144-162.

MacCallum, R. C., Browne, M. W., \& Sugawara, H. M. (1996). Power analysis and determination of sample size for covariance structure modeling. Psychological methods, 1(2), 130-149.

Maddux, J. E. (2002). Self-efficacy: The power of believing you can. In C. R. Snyder, \& S. J. Lopez (Eds.), Handbook of positive psychology (pp. 277-287). New York, NY, US: Oxford University Press.

Mills, N., Pajares, F., \& Herron, C. (2006). A reevaluation of the role of anxiety: Self-efficacy, anxiety, and their relation to reading and listening proficiency. Foreign Language Annals, 39(2), 276295.

Öner, G., \& Gedikoğlu, T. (2007). Ortaöğretim öğrencilerinin İngilizce öğrenimlerini etkileyen yabanc1 dil kaygısı. Gaziantep Üniversitesi Sosyal Bilimler Dergisi, 6(2), 144-155.

Pajares, F. (2002). "Overview of Social Cognitive Theory and of Self Efficacy" Retrieved from http://www.uky.edu/ eushe2/Pajares/eff.html.

Prudon, P. (2015). Confirmatory factor analysis as a tool in research using questionnaires: a critique. Comprehensive Psychology, 4 (10), 1-19, doi: https://doi.org/10.2466\%2F03.CP.4.10.

Rahemi, J. (2007). Self efficacy in English and Iranian senior high school students majoring in humanities. Novitas-Royal, 1(2), 98-111.

Rahimi, A., \& Abedini, A. (2009). The interface between EFL learners' self-efficacy concerning listening comprehension and listening proficiency. Novitas-Royal, 3(1), 14-28.

Raoofi, S., Tan, B. H., \& Chan, S. H. (2012). Self-efficacy in second/foreign language learning contexts. English Language Teaching, 5(11), 60-73.

Senemoğlu, N. (2000). Gelişim, ögrenme ve öğretim. Ankara: Gazi.

Sharp, C. (2002). Study support and the development of self-regulated learner. Educational Research, 44(1), 29-42.

Tabachnick, B. G., \& Fidell, L.S. (2007). Using Multivariate Statistics. Pearson Education. Boston, MA. 
Tilfarlioglu, F. T., \& Cinkara, E. (2009). Self-efficacy in EFL: Differences among proficiency groups and relationship with success. Novitas-Royal, 3(2), 129-142.

Todaka, Y. (2016). Self-efficacy of English listening skills in Japanese college EFL learners. International Journal of Education and Practice, 4(1), 21-36.

Tuncer, M., \& Tanaş, R. (2011). Eğitim fakültesi öğrencilerinin bilgisayar öz-yeterlik algılarının değerlendirilmesi. Adlyaman Üniversitesi Sosyal Bilimler Enstitüsü Dergisi, 4(6), 222-232.

Üncü, H. (2012). Akademik özyeterlik ölçeğinin Türkçe'ye uyarlanması. Ahi Evran Üniversitesi Kırşehir Eğitim Fakültesi Dergisi (KEFAD), 13(1), 183-206.

Weimer, M. (2002). Learner centered teaching: Five key changes to practice. San Francisco; JosseyBass.

Wheaton, B., Muthen, B., Alwin, D. F., \& Summers, G. F. (1977). Assessing reliability and stability in panel models. Sociological Methodology, 8, 84-136.

Yanar, H. B. (2008). Yabancı dil hazırlık eğitimi alan ve almayan anadolu lisesi ögrrencilerinin yabancı dil özyeterlik algilarının ve ingilizce dersine yönelik tutumlarının incelenmesi. (Unpublished master thesis). Ege Üniversitesi, İzmir.

Yanar, B. H., \& Bümen, N. T. (2012). İngilizce ile ilgili özyeterlik inancı ölçeğinin geliştirilmesi. Kastamonu Eğitim Dergisi, 20(1), 97-110.

Yang, N. D. (1999). The relationship between EFL learners' beliefs and learning strategy use. System, 27(4), 515-535.

Yıldırım, A., ve Şimşek, H. (2006). Sosyal bilimlerde nitel araştırma yöntemleri. Ankara: Seçkin Yayıncilik.

Yıldız, C. (2014). Müziksel işitme, okuma ve yazma öz yeterlik ölçeği'nin gelişstirilmesi ve müzik ögretmeni adaylarının öz yeterlik düzeylerinin bazı değişkenler açısından incelenmesi. (Unpublished master thesis). İnönü Üniversitesi, Malatya.

Zheng, D., Young, M. F., Brewer, R. A., \& Wagner, M. (2009). Attitude and self-efficacy change: English language learning in virtual worlds. CALICO journal, 27(1), 205-231.

Zimmerman, B. J. (2000). Self-efficacy: An essential motive to learn. Contemporary Educational Psychology, 25, 82-91. 